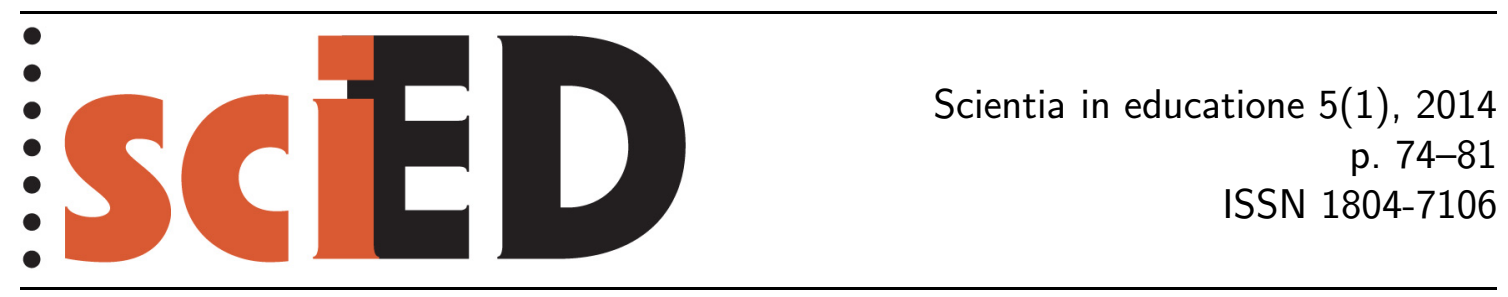

\title{
Význam nezávislých expertních center pro šírení badatelsky orientované výuky v České republice
}

\author{
Jan Činčera
}

\begin{abstract}
Abstrakt
Článek diskutuje problémy související s rozšǐřením tzv. badatelsky orientované výuky $(\mathrm{BOV}) \mathrm{v}$ českém prostředí. $\mathrm{V}$ první části poskytuje přehled publikovaných odborných textů zabývajících se BOV v českém kontextu. Ve druhé jsou shrnuty zkušenosti, které s touto metodikou získala tzv. nezávislá expertní centra, tj. organizace poskytující školám výukové a tréninkové programy. Stručně jsou charakterizovány jednotlivé realizované programy BOV a výsledky jejich evaluace. V poslední části článek uvádí argumenty pro větší spolupráci mezi těmito centry a univerzitami při šśření BOV.
\end{abstract}

Klíčová slova: nevládní organizace, badatelsky orientované vyučování, evaluace, environmentální výchova.

\section{The Importance of Independent Expert Centres for Dissemination of Inquiry-based Learning Approach in the Czech Republic}

\begin{abstract}
The paper discuses problems connected with dissemination of the inquiry-based learning (IBL) approach in the Czech educational environment. In the first part, it provides an overview of published papers focusing in the Czech context on IBL. In the next part, it summarizes experience with this approach obtained by so called independent expert centres, e.g. organisations providing educational and training programmes to schools. There are briefly described various IBL programmes and the results of their evaluation. In the last part the paper provides reasons for a higher cooperation between these centres and universities in the process of dissemination of the IBL.
\end{abstract}

Key words: non-governmental organisations, inquiry-based learning, evaluation, environmental education. 


\section{1 ÚVOD}

Badatelsky orientované vyučování (BOV) představuje relativně nový přístup $\mathrm{k}$ výuce přírodovědných předmětů. Přestože vymezit co je a co není BOV není zcela jednoduché, zpravidla se tímto pojmem označuje holistický, pedocentricky orientovaný přístup k výuce prrírodních věd, ve kterém žáci postupují podobně, jako skuteční vědci, tj. formulují výzkumné otázky a hypotézy, plánují výzkum, sbírají, vyhodnocují, interpretují a prezentují data (Magnussen, Ishida \& Itano, 2000; Hmelo-Silver, 2004; Ashby, 2006; Papáček, 2010a).

V České republice problematiku BOV otevřeli Papáček (2010a) a Stuchlíková (2010), kteří v domácím diskursu vymezili její základní terminologii. Papáček (2010a, 2010b) současně diskutoval možné bariéry bránící rozšíření BOV v České republice. Ty jsou podle jeho názory spojeny především s nároky, které BOV klade a na něž učitelé nejsou ze své pregraduální př́pravy dostatečně připraveni. S odstupem čtyř let se jeho obavy jeví být oprávněné. Přes úsilí Jihočeské univerzity a dalších pracovišt se BOV stále nestala běžnou součástí výuky přírodních věd. Domácí studie věnované BOV jsou poměrně nepočetné a lze je rozdělit do několika skupin.

V první jsou práce, které obecně charakterizují BOV, diskutují její terminologii a specifické rysy a shrnují očekávání, která jsou s tímto přístupem spjata. Základní rysy BOV vymezuje Dostál (2013) a přiřazuje je ke konstruktivistickému přístupu v pedagogice. Obdobně jako Papáček (2010a, b) považuje za jednu z bariér ššření BOV nedostatečné kompetence učitelů. Held (2011) předpokládá, že BOV reprezentuje koncepční posun ve výuce chemie, ke kterému v současné době v Evropě dochází. Kubicová (2013) se domnívá, že BOV může hrát důležitou úlohu v dosažení cílů environmentální výchovy. Zámečníková (2013) předpokládá, že BOV pomůže zvýšit oblibu prŕrodních věd u žáků a zvýší u nich pochopení sledovaných jevů.

Druhou skupinu tvoří studie, které předkládají návrhy vyučovacích hodin vedených podle principů BOV. Samková (2011) navrhuje využití BOV ve výuce matematiky, Bílek a Hrubý (2014) ve výuce chemie, Přinosilová, Mechlová a Kubicová (2013) se zabývají výpočetní technikou a environmentální výchovou, další př́ílady nabízí Mokrejšová (2010).

Třetí skupinou pak jsou práce, které ověřují efektivitu různým způsobem zpracovaných hodin a programů BOV. Ryplová a Řeháková (2011) ověřovaly efekt BOV hodiny využívající interaktivní tabuli na znalosti žáků. Činčera (2011) hodnotil vliv programu Společnosti pro Jizerské hory na vybrané badatelské dovednosti, Cinčera a Mašková (2011) pak sledovali tytéž kompetence u programu GLOBE koordinovaného Sdružením TEREZA.

Relativně malý počet domácích studií ověrujících vliv BOV na vybrané proměnné může být zarážející ve srovnání se zahraniční literaturou, kde jsou takové práce poměrně běžné (např. Sumerlee \& Murray, 2010; Magnussen, Ishida \& Itano, 2000; Gautreau \& Binns, 2012; Kuech, 2004; Pea, 2012; Ballantyne, Packer \& Everett, 2005; Cronje, Rohlinger, Crall \& Newman, 2011). Nabízí se proto otázka, jak domácí výzkum BOV posílit a přispět tak k jejímu dalšímu rozššřrení. Článek diskutuje, jakou roli mohou pro dosažení těchto cílů hrát tzv. nezávislá expertní centra a jakým způsobem by s nimi mohly spolupracovat fakulty připravující budoucí učitele. 


\section{NEZÁVISLÁ EXPERTNí CENTRA A BADATELSKY ORIENTOVANÁ VÝUKA}

Jako „nezávislá expertní centra“ zde budeme chápat organizace, které realizují či poskytují výchovně-vzdělávací či tréninkové programy školám a pedagogickým pracovníkům a nemají status školy či školského zařízení. Pojem zde používáme v podobném, ale širším smyslu, než jsou často používané termíny „nevládní organizace“ či „střediska ekologické výchovy“, které nemusí pokrývat všechny typy organizací, jež odpovídají výše uvedené definici. V České republice je tento typ organizací značně rozšiřen. Kulich (2009) uvádí, že jen v oblasti environmentální výchovy u nás působilo přes sto padesát organizací, více než polovina z nich pak měla charakter občanských sdružení (od roku 2014 se právní status těchto organizací v důsledku novelizace právních úprav změnil).

Pojmem „program“ pak budeme chápat sekvenci aktivit, které naplňují jeden či více společných cílů (Newcomer, Hatry \& Wholey, 2004; DEC, 2004; Simmons, 2004) a které fungují jako smysluplné celky. „Program BOV“ pak je takový program, který jako celek (nebo z větší části) respektuje zásady badatelsky orientované výuky, tj. vede žáky k formulování výzkumných otázek a hypotéz, k plánování a realizaci výzkumu, analýze, interpretaci a prezentaci získaných dat.

V řadě zemí jsou programy BOV nabízené školám nezávislými expertními centry poměrně běžné. Ve Velké Británii mají velkou tradici centra sdružená do sítě tzv. Field Studies Councils (FSC). Např́klad v pětidenním pobytovém programu centra ve skotském Kindroganu „Biology Advanced Higher Residential Programme: Pilot Projects and Project Data Collection“ prochází žáci celým badatelským cyklem, tj. nejprve se učí formulovat hypotézy, poté plánují výzkum a sbírají data, ze kterých pak po návratu zpracují vlastní výzkumnou zprávu (Činčera, vlastní pozorování 2011; Kindrogan Field Studies Council, 2014). Jednodenní terénní program zaměřený na zkoumání zatopeného území nabízí v holandském Wageningen organizace Groene Wiel (Činčera, vlastní pozorování 2013). Tzv. „př́írodní centrum“ na ostrově Harakka v Helsinkách nabízí školám jednodenní programy, ve kterých žáci zkoumají mořský život či let ptáků (Činčera, vlastní pozorování 2012).

V České republice nabízejí nezávislá expertní centra několik typů programů, které vycházejí z principů BOV. Prvním typem jsou pobytové programy, ve kterých žáci stráví více než jeden den v terénním centru, ze kterého pak vyrážejí sbírat data do okolní přírody. S tímto modelem, který je typický pro britské FSC, se můžeme setkat u několika organizací. Středisko ekologické výchovy a etiky Rýchory (SEVER) nabízí pětidenní program nazvaný Týden pro udržitelný život (Kvasnička, 2012). Program obsahuje spíše dílčí prvky, než celou metodiku BOV. Žáci se v programu učí rozpoznávat znaky zdravého lesa, měři čistotu potoka a vyhodnocují stav okolního životního prostředí. Realizovaná evaluace programu naznačila možný vliv na formování environmentálních postojů žáků a jejich odhodlanost k proenvironmentálnímu chování (Činčera, 2011).

Druhým typem jsou dlouhodobé školní programy, pro které centrum připraví metodické materiály a vyškolí učitele, kteří pak program vedou. Tento typ programů nabízí především Sdružení TEREZA. Nejstarším badatelským programem, který centrum nabízí, je mezinárodní program GLOBE, který u nás probíhá již od roku 1995. Do programu je v České republice zapojeno přibližně 130 základních a středních škol. V rámci programu žáci především sbírají data o životním prostředí (část škol pak na základě naměřených dat realizuje vlastní projekty zaměřené na problémy životního prostředí). Evaluace ukázala, že hlavním limitem programu je jeho 
implementace na školách. Učitelé v programu kladli př́lišs velký důraz na sběr dat, a to na úkor poskytování př́iležitosti žákům vymezit si vlastní výzkumné otázky a analyzovat a interpretovat výsledky. Zapojení do programu tak pravděpodobně posiluje přírodovědné znalosti žáků, ale nerozvíjí dostatečně jejich badatelské dovednosti (Činčera \& Mašková, 2009, 2011). Program se ale v současnosti dále vyvíjí a posiluje využití principů BOV pro samostatnou práci žáků.

Dalšími programy BOV realizovanými Sdružením TEREZA byly: „3V - vědě a výzkumu vstř́ic", který byl určený pro střední školy, a „Badatelé.cz", program pro základní školy. Oba programy usilovaly o rozvoj badatelských dovedností žáků a o větší rozšíření metodiky BOV na českých školách. Oba vznikaly také ve spolupráci s experty z vysokých škol, kteří se podíleli na jejich připomínkování a evaluaci, a učiteli základních a středních škol, kteří navrhovali a ověřovali jednotlivé badatelské lekce. Program Badatelé.cz rozvinul u žáků ze zapojených škol porozumění principům vědecké práce (badatelský cyklus) a vybrané badatelské dovednosti. Byl rovněž velmi dobře hodnocen žáky i zapojenými učiteli (Činčera, 2013a; v tisku).

Posledním typem jsou programy, které jsou z části realizovány ve škole a z části nezávislým expertním centrem. Příkladem jsou programy realizované Společností pro Jizerské hory a sdružením Čmelák. Program „Vyšetřování jizerskohorské katastrofy - pro 7.-9. tř́idu ZŠS“ prováděla Společnost pro Jizerské hory. Začínal ve škole, kde byli žáci seznámeni s historickými příčinami poškození lesů v Jizerských horách v 80. letech 20. století. Žáci si měli připravit zadání svého výzkumu, a ten pak realizovat v rámci pobytové terénní části programu ve středisku Jizerka. Návrh programu i jeho evaluace probíhaly ve spolupráci s Technickou univerzitou v Liberci. Evaluace ukázala, že slabou částí programu byla implementace jeho školní části, ze které žáci často přijížděli na Jizerku bez připraveného výzkumu. Na druhé straně program posílil některé badatelské kompetence žáků a porozumění zkoumanému problému (Činčera, 2011).

Program „Zelené profese v krajině“ realizovaný libereckým sdružením Čmelák předpokládal, že žáci se nejprve ve škole pomocí pracovních listů seznámí s některými zaměstnáními souvisejícími s péčí o krajinu (např. lesnictví, vodohospodářství). V navazující pobytové části v terénní základně v Jizerských horách se pak žáci učili jednotlivé techniky sběru a vyhodnocení dat. Poslední částí byl projekt, ve kterém si žáci samostatně zformulovali svoji výzkumnou otázku, a tu pak experimentálně ověrovali. Výsledky evaluace byly bohužel zkresleny malým počtem respondentů a chybami v administraci, takže program nebylo možné spolehlivě vyhodnotit (Činčera, 2014).

\section{Diskuse}

Přestože malý počet ověřených programů BOV realizovaných nezávislými expertními centry neumožňuje zobecnění, nabízí $\mathrm{k}$ diskusi několik témat. Ve shodě s Papáčkem (2010a, 2010b) či Dostálem (2013) se zdá být patrné, že programy BOV mohou být pro učitele náročné a chyby $\mathrm{v}$ implementaci na školách mohou snížit jejich přínos pro žáky. Úspěch programu Badatelé.cz mohl být na druhé straně způsobený tím, že učitelé tvořili od začátku projektu společný tým s pracovníky nezávislého expertního centra, vzájemně si své programy připomínkovali, a v důsledku toho pro ně byla metodika BOV srozumitelná. Je možné, že dokud se výuka BOV nestane běžnou součástí pregraduální přípravy učitelů, nabízí tento model štastné východisko. 
Rozdíly v úspěšnosti jednotlivých programů BOV ukazují, že tato metodika je poměrně náročná i pro nezávislá expertní centra. Pro nastavení dobře fungujícího programu proto hrají důležitou roli univerzity, které mohou připomínkovat obecnější nastavení programu či jeho odbornou správnost. Univerzity navíc mohou spolupracovat s nezávislými expertními centry na evaluaci realizovaných programů, v čemž mohou využít své metodologické zázemí i nestranné postavení.

Na druhé straně lze předpokládat, že nezávislá expertní centra disponují specifickými tacitními znalostmi, které vyplývají z jejich zkušenosti s podobnými programy a jejich implementací, a které jsou pro univerzitní odborníky nedostupné. Tento typ informací pak může být zásadní pro praktický transfer metodiky směrem $\mathrm{k}$ učitelům v praxi či studentům učitelství na vysokých školách. Spolupráce založená na vzájemném respektu a oboustrannému porozumění významu proto může hrát klíčovou roli pro sestavení dobře fungujícího programu BOV.

Význam nezávislých expertních center bývá někdy snižován a jejich relativně silné postavení v některých specifických oblastech výchovy a vzdělávání kritizováno. Napřr. Kvasničková (2010) považuje poskytování metodických materiáli̊ školám za „velmi problematické“ a obává se, že se tak školy zbavují odpovědnosti za výuku. Kritizuje dále rozsah finančních prostředků, které nezávislá expertní centra díky grantové podpoře dostávají, a zpochybňuje odborné a metodické kvality lektorů těchto center. Na druhé straně, ani vztah nezávislých expertních center k vysokým školám není bezproblémový. Mezi lektory tzv. stř̌edisek ekologické výchovy je poměrně rozšǐřené negativní hodnocení fakult vzdělávajících budoucí učitele. Podle jejich názoru jsou odříznuté od praxe a nedokážou budoucí učitele naučit potřebné metodické postupy (Činčera, 2013b).

Jakkoliv je třeba předpokládat, že mezi nezávislými expertními centry existují velké rozdíly, pokud jde o kvalitu jejich služeb, je zřejmé, že ve specifických výchovněvzdělávacích oblastech, které nejsou dostatečně pokryty pregraduální přípravou učitelů (jako je BOV), hrají tato centra velmi důležitou roli. Nezávislá expertní centra se tak stávají určitým mezičlánkem zprostředkujícím školám aplikované metodické postupy odvozené od teorie, kterou samotné univerzity nejsou zatím schopny adekvátním způsobem předávat do praxe. Pro úspěšné šiřrení BOV, ale i jiných metodických př́stupů, je proto důležité tuto roli nezávislých expertních center podpořit. To předpokládá nalézt takový model funkční spolupráce mezi univerzitami, nezávislými expertními centry i školami, který je založený na vzájemném respektu a akceptování významu a role jednotlivých partnerů.

\section{ZÁvĚr}

Cílem článku bylo diskutovat, jakou roli mohou hrát tzv. nezávislá expertní centra při rozvoji badatelsky orientované výuky a jakým způsobem by s nimi mohly spolupracovat fakulty připravující budoucí učitele. Nezávislá expertní centra u nás v posledních letech realizovala několik programů BOV, které byly vyhodnoceny pomocí metod evaluačního výzkumu, a významným způsobem tak přispěla jak k šíření tohoto př́istupu do škol, tak k posílení našeho porozumění tomu, jak funguje. Pro další rozvoj BOV je proto důležité hledat modely funkční spolupráce mezi nezávislými expertními centry, školami a univerzitami. Jestliže v současné době můžeme vnímat vztah mezi univerzitami a nezávislými expertními centry jako problematický, je důležité pokusit se najít cesty k oboustranně výhodné spolupráci, založené na vzájemném respektu. 


\section{LITERATURA}

Ashby, J., Hubbert, V., Cotrel-Gibbons, L., Cox, K., Digan, J., Lewis, K. \& Wilson, L. (2006). The enquiry-based learning experience: an evaluation project. Nurse Education in Practice, 6(1), 22-30. doi: 10.1016/j.nepr.2005.05.008

Ballantyne, R., Packer, J. \& Everett, M. (2005). Measuring environmental education program impacts and learning in the field: Using an action research cycle to develop a tool for use with young students. Australian Journal of Environmental Education, 21, $23-37$.

Bílek, M. \& Hrubý, J. (2014). Počítačem podporovaný školní chemický experiment jako prostredek badatelsky orientovane výuky. Retreived from: http://chemistrynetwork.pixelonline.org/data/SUE_db/doc/56_Chemistry\%20-\%20Bilek\%20-\%20Hruby.pdf

Činčera, J. (2011). Rozvoj výzkumných kompetencí žáků na základní škole - zkušenosti z evaluace programu o Jizerských horách. Envigogika: Charles University E-journal for Environmental Education, 6(3). Retrieved from http://www.envigogika.cuni.cz/index.php/Envigogika/article/view/63

Činčera, J. (2012). Evaluace orientovaná na uživatele: zkušenost s pobytovým programem Člověk a prostředí. Orbis Scholae, 6(3), 119-134. Retrieved from http://www.orbisscholae.cz/archiv/2012/2012_3_06.pdf

Činčera, J. (2013a). Badatelé.cz: evaluační zpráva. Interní dokument. Praha: Sdružení TEREZA.

Činčera, J. (2013b). Střediska ekologické výchovy mezi teorii a praxí. Praha: BEZK, Agentura Koniklec a Masarykova univerzita.

Činčera, J. (2014). Zelené profese v krajině - evaluační zpráva. Interní dokument. Liberec: Čmelák - společnost přátel přírody.

Cinčera, J. (v tisku) To think like a scientist: an experience from the Czech primary school inquiry-based learning programme. The New Educational Review.

Činčera, J. \& Mašková, V. (2009). GLOBE v Ceské republice: evaluace programu. Interní dokument. Praha: Sdružení TEREZA.

Činčera, J. \& Maskova, V. (2011). GLOBE in the Czech Republic: a program evaluation. Environmental Education Research, 17(4), 499-517. doi: 10.1080/13504622.2011.557497

Cronje, R., Rohlinger, S., Crall, A. \& Newman, G. (2011). Does participation in citizen science improve scientific literacy? A study to compare assessment methods. Applied Environmental Education \& Communication, 10(3), 135-145. doi:

10.1080/1533015X.2011.603611

DEC (2004). DOES Your Project Make a Difference? Sydney: Department of Environment and Conservation. Retrieved from http://www.environment.nsw.gov.au/resources/community/projecteval04110.pdf

Dostál, J. (2013). Badatelsky orientovaná výuka jako trend soudobého vzdělávání. E-Pedagogium, 3, 81-93.

Gautreau, B. T. \& Binns, I. C. (2012). Investigating student attitudes and achievements in an environmental place-based inquiry in secondary classrooms. International Journal of Environmental \& Science Education, 7(2), 167-195.

Held, L. (2011). Konfrontácia koncepcií přrírodovědného vzdelávania v Európe. Scientia in educatione, 2(1), 69-79. 
Hmelo-Silver, C. E. (2004). Problem-based learning: What and how do students learn? Educational Psychology Review, 16(3), 235-266. doi: 1040-726X/04/0900-0235/0

Kindrogan Field Studies Council (2014). Biology Advanced Higher Residential Programme: Pilot Projects and Project Data Collection. Retrieved from http://www.field-studies-council.org/documents/outdoorclassroom/ recommended_courses/Scotland/Advanced\%20Higher/Biology/ AH\%20B\%203,\%204,\%205\%20days.pdf

Kubicová, S. (2013). Environmentální vzdělávání žáků ZŠ a SŠ s edukační podporou „inquiry“ činností. In Sehnalová V. (Ed.), Sborník rozšírených anotací Baličku odborných kompetencí. Ostrava: Ostravská univerzita, 56-59.

Kuech, R. (2004). Collaborative and interactional processes in an inquiry-based, informal learning environment. The Journal of Classroom Interaction, 39(1), 30-41.

Kulich, J. (Ed.) (2009). Analýza potřebnosti a využití environmentálních vzdělávacích center na území České republiky. Hlavní zjištění 2009. Horní Maršov: SEVER, Agentura Koniklec, BEZK.

Kvasnička, J. (Ed.) (2012). Týden pro udržitelný život - vzdělávací program pro žáky ZS̆ a $S \breve{S}$. Horní Maršov: SEVER.

Kvasničková, D. (2010). K pojetí vzdělávání pro udržitelný rozvoj. In The international conference on Education. Education \&5 sustainable life. 23.-26. 10. 2010 (167-176).

Svatý Jan pod Skálou: Centrum ekologického výzkumu a výchovy.

Magnussen, L., Ishida, D. \& Itano, J. (2000). The impact of the use of inquiry-based learning as a teaching methodology on the development of critical thinking. Journal of Nursing Education, 39(8), 360-365.

Mokrejšová, O. (2010). Některé možnosti aktivní výuky př́rodovědných témat na základních školách. In Fragmenta Ioannea collecta, supplementum 2010. The international conference on education. Education \&3 sustainable life. 23.-26. 10. 2010 (21-34). Svatý Jan pod Skálou: Centrum ekologického výzkumu a výchovy.

Newcomer, K. E., Wholey, J. S. \& Hatry, H. P. (2004). Meeting the Need for Practical Evaluation Approaches: An Introduction. In Newcomer, K. E., Wholey, J. S. \& Hatry, H. P. (Eds.) Handbook of Practical Program Evaluation (xxxiv). San Francisco: Jossey-Bass.

Papáček, M. (2010a). Badatelsky orientované přírodovědné vyučování - cesta pro biologické vzdělávání generací Y, Z a alfa? Scientia in educatione, 1(1), 33-49.

Papáček, M. (2010b). Limity a šance zavádění badatelsky orientovaného vyučování př́rodopisu a biologie v Ceské republice. In M. Papáček (Ed.), Didaktika biologie v České republice 2010 a badatelsky orientované učení. DiBi 2010. Sborník př́spěvkĩ semináře, 25.-26. 3. 2010 (145-162). České Budějovice: Jihočeská univerzita.

Pea, C. H. (2012). Inquiry-based instruction: Does school environmental context matter? Science Educator, 21(1). Retrieved from http://www.highbeam.com/doc/1P3-2771193041.html

Přinosilová, J., Mechlová, E. \& Kubicová, S. (2013). ICT on four levels of inquiry-based science education in environmental education. ICTE Journal, 2, 1, 17-31.

Ryplová, R. \& Řeháková, J. (2011). Přínos badatelsky orientovaného vyučování (BOV) pro environmentální výchovu: př́padová studie implementace BOV do výuky ZS̆.

Envigogika: Charles University E-journal for Environmental Education, 6(3). Retrieved from, http://www.envigogika.cuni.cz/index.php/Envigogika/article/view/65 
Samková, L. (2011). Badatelsky orientované vyučování matematiky. Retrieved from: http://home.pf.jcu.cz/ upvvm/2011/sbornik/clanky/36_UPVM11_Samkova.pdf

Simmons, B. (Ed.) (2004). Nonformal Environmental Education Programs - Guidelines for Excellence. Washington: North American Association for Environmental Education.

Stuchlíková, I. (2010). O badatelsky orientovaném vyučování. In M. Papáček (Ed.), Didaktika biologie v České republice 2010 a badatelsky orientované učení. DiBi 2010. Sbornik př́spěvků semináře, 25.-26. 3. 2010 (129-135). Ceské Budějovice: Jihočeská univerzita.

Summerlee, A. \& Murray, J. (2010). The impact of enquiry-based learning on academic performance and student engagement. Canadian Journal of Higher Education, 40(2), $78-94$.

Zámečníková, V. (2013). Badatelsky orientovaná výuka se zaměřením na obecnou a anorganickou chemii. In Laufková, V., Moraová, H. \& Medřická, T. (Eds.), Metodologické př́stupy $v$ pedagogických a psychologických doktorských výzkumech (54-61). Recenzovaný sborník z doktorské konference konané dne 20. května 2013 v Praze. Praha: Univerzita Karlova.

\section{PODĚKOVÁNí}

Tento článek by nebyl možný bez dlouhodobé spolupráce s nezávislými expertními centry. Velmi si vážím jejich otevřenosti ke konstruktivní kritice i autentického zájmu o to „dělat dobré programy“. V neposlední řadě děkuji recenzentům za vstřícné přijetí celého textu.

JAN ČINČERA, jan.cincera@tul.cz

Masarykova Univerzita, Fakulta sociálních studií

Katedra environmentálních studií

Joštova 10, 60200 Brno, Česká republika

Technická univerzita v Liberci, Fakulta př́rodovědně-humanitní a pedagogická Katedra pedagogiky a psychologie 1. máje 870/14, 46003 Liberec 3, Česká republika 